\title{
Rekayasa Biopolimer Jerami Padi dengan Teknik Kopolimerisasi Cangkok dan Taut Silang
}

\author{
Henny Purwaningsih ${ }^{1,2}$, Tun Tedja Irawadi ${ }^{1,2}$, Zainal Alim Mas'ud ${ }^{1,2}$ Anas Miftah Fauzi ${ }^{1}$ \\ 1) Program Studi Teknologi Industri Pertanian, FATETA IPB \\ ${ }^{2)}$ Departemen Kimia FMIPA IPB \\ e-mail: hennypu@ipb.ac.id
}

\begin{abstract}
Abstrak
Kopolimerisasi cangkok dan taut silang akrilamida (AAm) terhadap jerami padi dilakukan dalam suasana hampa udara menggunakan aliran gas $\mathrm{N}_{2}$ dengan amonium persulfat (APS) sebagai inisiator dan $N, N$ '-metilena-bis-akrilamida (MBAAm). Pencirian dilakukan dengan teknik mikroskopi pemayaran elektron (SEM) untuk melihat morfologi permukaan, teknik spektroskopi FTIR untuk melihat gugus fungsi, dan teknik DTA untuk menganalisis ketahanan produk terhadap suhu. Kajian dilakukan terhadap swelling capacity produk hasil rekayasa. Spektra FTIR dan mikrograf menunjukkan bahwa kopolimerisasi cangkok dan taut silang telah terjadi pada biopolimer selulosa jerami padi. Produk hasil rekayasa memiliki ketahanan termal yang lebih baik dan indeks kristalinitas yang lebih tinggi dari isolat selulosanya. Nisbah dan efisiensi pencangkokan berturut-turut adalah 66,14-78.15\% dan 13,23-16.63\%. Swelling capacity sebelum proses hidrolisis berkisar antara 8,16$12,20 \mathrm{~g} \mathrm{~g}^{-1}$. Proses hidrolisis terhadap produk hasil rekayasa mampu meningkatkan swelling capacity hingga 12,5 kali kapasitas awal.
\end{abstract}

Kata kunci : biopolimer, kopolimerisasi, cangkok, taut silang, akrilamida

\begin{abstract}
The graft copolymerization and cross-linking of acrylamide (AAm) to rice straw has been carried out under $\mathrm{N}_{2}$ atmosphere using ammonium persulfate (APS) as initiator, followed by crosslinking reaction with N,N'-methylene-bis-acrylamide (MBAAm). Scanning electron microscopy (SEM), fourier transform infrared spectroscopy (FTIR), and differential thermal analysis (DTA) were used to characterize the morfology, functional groups, and thermal properties of grafted-crosslinked products. The products were also evaluated for their swelling capacity against water. The FTIR spectra and SEM micrographs behavior confirmed that graft copolymerization and cross-linking were succeed. The modified product showed better thermal properties and higher crystallinity index than cellulose isolate. Ratio and efficiency grafting were $66,14-78.15 \%$ and $13,23-16.63 \%$, respectively. Swelling capacity before hydrolisis was $8,16-12,20 \mathrm{~g} \mathrm{~g}^{-1}$. Swelling capacity was increased for 12,5 times after hydrolisis.
\end{abstract}

Keywords : biopolymer, copolymerization, grafting, crosslinking, acrylamide

\section{PENDAHULUAN}

Selulosa adalah polimer alam dengan kelimpahan yang banyak, tidak mahal, tidak beracun, mudah didegradasi, dan termasuk ke dalam sumberdaya alam yang dapat diperbarui. Saat ini, pemanfaatan selulosa sebagai bahan baku alternatif di dalam industri (starting material) cenderung meningkat. Hal ini disebabkan semakin berkurangnya jumlah cadangan bahan baku yang berasal dari sumberdaya alam yang tidak dapat diperbarui seperti minyak dan batu bara. Selain itu, perhatian dunia Internasional akan isu-isu yang 
terkait dengan masalah lingkungan pun cenderung meningkat. Selain memiliki beberapa keunggulan, selulosa juga memiliki kelemahan jika dibandingkan dengan polimer sintetik, yaitu adanya ikatan hidrogen intra- dan antarmolekul yang kuat pada selulosa sehingga sulit diakses oleh senyawa lain.

Modifikasi terhadap selulosa perlu dilakukan untuk memenuhi persyaratan dalam penerapannya di industri. Modifikasi kimia melalui kopolimerisasi cangkok dengan berbagai monomer sintetik diketahui dapat memperbaiki sifat-sifat seperti kemampuan menyerap air, elastisitas, kemampuan tukar ion, ketahanan terhadap termal, dan ketahanan terhadap serangan mikroba (McDowall et al. 1984).

Berbagai jenis polimer dapat dicangkok (grafting) ke rantai selulosa melalui gugus hidroksil pada posisi C2, C3, dan C6 (EnomotoRogers et al. 2009). Gugus hidroksil pada C2 dan C3 adalah gugus hidroksil yang terikat pada atom karbon sekunder, sedangkan gugus hidroksil pada C6 terikat pada atom karbon primer. Kereaktifan dan kemasaman gugus hidroksil primer dan sekunder ini berbeda. Dengan memilih monomer yang tepat, maka kekuatan mekanik dan stabilitas termal material berbasis selulosa yang dimodifikasi dengan teknik pencangkokan dapat ditingkatkan (Princi 2005). Selain itu, polisakarida yang telah dimodifikasi tersebut dapat menghasilkan produk berstruktur makromolekular seperti gel atau hidrogel, resin polimer, membran atau material komposit yang dapat diaplikasikan sebagai material separator dalam teknologi separasi (Crini 2005).

Beberapa kajian polimerisasi cangkok terhadap bahan berbasis selulosa telah banyak dilaporkan. Princi et al. (2005) melakukan modifikasi selulosa melalui kopolimerisasi cangkok menggunakan monomer metil metakrilat dan etil akrilat. Khan et al. (2009) melaporkan telah melakukan modifikasi pada permukaan serat kulit pohon Okra dengan teknik pencangkokan menggunakan monomer akrilonitril, inisiator $\mathrm{K}_{2} \mathrm{~S}_{2} \mathrm{O}_{8}$, dan katalis $\mathrm{FeSO}_{4}$. Rendemen produk hasil pencangkokan diperoleh sebesar $11.43 \%$ pada suhu $70{ }^{\circ} \mathrm{C}$ selama 90 menit menggunakan $3 \times 10^{-2}$ mol akrilonitril, $5 \mathrm{x}$ $10^{-3} \mathrm{~mol} \mathrm{~K}_{2} \mathrm{~S}_{2} \mathrm{O}_{8}$. El-Mohdy dan El-Rehim (2009) memodifikasi kappa-karagenan ( $\mathrm{\kappa C})$ melalui kopolimerisasi cangkok akrilamida menggunakan irradiasi $\gamma$ diikuti dengan hidrolisis menggunakan larutan alkali. Produk akhir yang diperoleh berupa hidrogel yang bersifat superabsorben dengan kemampuan menyerap (swelling capacity) mencapai 10 kali di dalam air destilata dan 3 kali dalam larutan $\mathrm{NaCl}$.

Huang et al. (2009) melaporkan telah memodifikasi ampas tebu yang terlebih dahulu diaktivasi secara mekanik, lalu dilanjutkan dengan kopolimerisasi cangkok menggunakan monomer asam akrilat dan pasangan redoks $\mathrm{NH}_{2} \mathrm{~S}_{2} \mathrm{O}_{8} / \mathrm{Na}_{2} \mathrm{SO}_{3}$ sebagai inisiator. Hasil yang diperoleh menunjukkan bahwa aktivasi secara mekanik mempengaruhi sifat produk kopolimerisasi cangkok ampas tebu, dimana rendemen dan efisiensi pencangkokan meningkat dengan meningkatnya waktu aktivasi. Doane et al. (2009) juga melaporkan telah melakukan modifikasi pati yang berasal dari berbagai sumber dengan teknik pencangkokan dilanjutkan dengan taut silang untuk mendapatkan polimer superabsorben dengan kemampuan menyerap yang cukup tinggi.

Di Indonesia, jerami padi adalah limbah pertanian yang dihasilkan dalam jumlah cukup banyak setiap tahunnya. Menurut Kim dan Dale (2004), nisbah jerami padi terhadap padi yang dipanen adalah 1.4 , artinya untuk menghasilkan 1 ton padi akan menghasilkan 1.4 ton jerami padi. Pada tahun 2011, total produksi padi menurut data BPS mencapai 67.31 juta ton, sehingga jerami padi akan diperoleh sebanyak 94.23 juta ton. Selama ini jerami padi di Indonesia belum dimanfaatkan secara optimal. Sebagian besar jerami padi dibakar setelah proses penggabahan selesai.

Dari berbagai kajian diketahui bahwa komponen utama dinding sel pada jerami padi adalah selulosa. Kandungan selulosa yang cukup besar ini menjadikan jerami padi sebagai sumber selulosa yang cukup potensial. Menurut Sun et al. (2000), komposisi jerami padi terdiri atas selulosa $36,5 \%$, hemiselulosa $33,8 \%$, lignin $12,3 \%$, bahan ekstraktif $3,8 \%$, abu $13,3 \%$, dan silika $70,8 \%$.

Penelitian ini bertujuan mendapatkan (1) produk kopolimerisasi cangkok akrilamida dan taut silang $N, N$ '-metilena-bis-akrilamida sebagai suatu upaya rekayasa biopolimer dari selulosa 
jerami padi; (2) karakteristik produk hasil rekayasa yang dilakukan melalui analisis gugus fungsi dengan teknik spektroskopi IR (infrared), analisis morfologi permukaan dengan teknik mikroskopi pemayaran elektron, analisis termal, dan kemampuannya dalam menyerap air (swelling capacity).

\section{METODE PENELITIAN}

\section{Bahan}

Isolat selulosa dari jerami padi, akrilamida (AAm, E.Merck) digunakan sebagai monomer, amonium persulfat (APS, E.Merck) digunakan sebagai inisiator, dan $N, N$ '-metilenabis-akrilamida (MBAAm, E.Merk) digunakan sebagai penaut silang. Bahan kimia lainnya seperti aseton (E.Merk), metanol (E.Merk), etanol (E.Merk), $\mathrm{NaOH}$ (E-Merck).

\section{Kopolimerisasi Cangkok Akrilamida dan Taut Silang $N, N$ '-Metilena-bis-Akrilamida}

Sebanyak $25 \mathrm{~g}$ selulosa hasil isolasi dimasukkan ke dalam reaktor lalu ditambahkan $150 \mathrm{ml}$ air destilata, kemudian dipanaskan pada suhu $95{ }^{\circ} \mathrm{C}$ dan diaduk dengan kecepatan 200 rpm selama 30 menit. Setelah itu, suhu diturunkan sampai kira-kira $60-65^{\circ} \mathrm{C}$. Ke dalam reaktor dimasukkan larutan APS (250 mg APS dalam 12,5 $\mathrm{ml}$ air destilata) dan suhu dijaga pada kisaran $60-65{ }^{\circ} \mathrm{C}$ selama 15 menit. Setelah itu, ke dalam reaktor ditambahkan larutan monomer AAm dan penaut silang MBAAm dengan kecepatan 0,5 ml/detik (25 g AAm ditambah 0,1 g MBAAm dilarutkan dalam $200 \mathrm{ml}$ ). Setelah semua pereaksi dimasukkan, suhu reaktor dinaikkan menjadi $70{ }^{\circ} \mathrm{C}$ dan dipertahankan sampai 3 jam. Selanjutnya, reaktor didinginkan dan produk hasil sintesis diperoleh dalam bentuk gel. Untuk menghilangkan sisa monomer atau homopolimer yang terbentuk, gel yang diperoleh direndam berturut-turut ke dalam $150 \mathrm{ml}$ metanol p.a selama 30 menit, $150 \mathrm{ml}$ etanol p.a selama 30 menit, dan $150 \mathrm{ml}$ aseton p.a selama 1 jam. Kemudian gel dikeringkan pada suhu 60 ${ }^{\circ} \mathrm{C}$. Pengaruh jumlah pereaksi penaut silang dipelajari dengan cara memvariasikan jumlah penaut silang $(0,1 ; 0,5$; dan $1 \mathrm{~g})$. Keberhasilan kopolimerisasi cangkok dan taut silang ini dievaluasi melalui nisbah pencangkokan dan efisiensi pencangkokan.

$$
\text { Nisbah Pencangkolan }=\frac{100\left[\mathrm{~N}(\%) \times\left(\frac{\mathrm{BM} \text { Akrilamida }}{\mathrm{BM} \text { Atom }}\right)\right]}{100-\left[\mathrm{N}(\%) \times\left(\frac{\mathrm{BM} \text { Akrilamida }}{\mathrm{BMAtomN}}\right)\right]}
$$

Efisiensipencangkolan $(\%)=\frac{\text { Nisbahpencangkolan }}{\% \text { monomerterhadappreparatsampel }} \times 100 \%$

\section{Analisis Gugus Fungsi dengan Spektrometer FTIR}

Spektra IR isolat selulosa direkam melalui spektrometer FTIR Perkin Elmer Spectrum One menggunakan pelet $\mathrm{KBr}$ dari bilangan gelombang $4000 \mathrm{~cm}^{-1}$ sampai $400 \mathrm{~cm}^{-1}$ dengan resolusi $8 \mathrm{~cm}^{-1}$ dan pemayaran $45 \mathrm{x}$ per contoh.

\section{Analisis Morfologi Permukaan dengan Mikroskop Elektron Pemayaran (Scanning Electron Microscope, SEM)}

Produk hasil isolat ditempelkan di atas tempat contoh menggunakan perekat elektrokonduktif. Pengamatan morfologi dilakukan pada JEOL 6400 mikroskop elektron dengan tegangan $20 \mathrm{kV}$.

\section{Analisis Termal dengan TG/DTA}

Thermogravimetric (TG) dan differential thermogravimetric analysis (DTA) dilakukan dengan DTG-60H FC-60A TA-60WS. Suhu yang digunakan mulai suhu kamar sampai 600 ${ }^{\circ} \mathrm{C}$ dengan laju pemanasan $10{ }^{\circ} \mathrm{C}$ menit ${ }^{-1}$.

\section{Swelling Capacity}

Sejumlah produk hasil modifikasi direndam dalam air destila dan disimpan pada suhu kamar sampai kesetimbangan proses pengembangan tercapai. Produk yang telah mengembang dipisahkan dari air yang tidak terserap. Swelling capacity $\left(\mathrm{Q}_{\mathrm{H} 2 \mathrm{O}}\right)$ ditentukan dengan menimbang produk yang telah mengembang dan dihitung dengan menggunakan persamaan:

$$
\mathrm{Q}_{\mathrm{H}_{2} \mathrm{O}}=\frac{\mathrm{m}_{2}-\mathrm{m}_{1}}{\mathrm{~m}_{1}}
$$


$\mathrm{m}_{1}$ dan $\mathrm{m}_{2}$ adalah bobot contoh kering dan contoh yang telah mengembang $(\mathrm{g})$. $\mathrm{Q}_{\mathrm{H} 2 \mathrm{O}}$ dinyatakan sebagai gram air per gram contoh $(\mathrm{g}$ $\left.\mathrm{g}^{-1}\right)$.

\section{Hidrolisis.}

Produk hasil pencangkokan direfluks menggunakan larutan $\mathrm{NaOH}$ 1,5\% selama 2 jam dengan perbandingan padatan:larutan adalah 1:25. Setelah hidrolisis, contoh dicuci menggunakan akuades sampai $\mathrm{pH}$ netral. Produk yang telah dihidrolisis selanjutnya diuji swelling capacity-nya.

\section{HASIL DAN PEMBAHASAN}

\section{Kopolimerisasi Cangkok dan Taut Silang}

Rekayasa biopolimer jerami padi dilakukan melalui reaksi kopolimerisasi cangkok AAm dan taut silang MBAAm dengan inisiator APS. Biopolimer berupa isolat selulosa dari jerami padi dijadikan kerangka utama (backbone) dalam reaksi pencangkokan. Kopolimerisasi cangkok dan taut silang yang berlangsung dalam penelitian ini tidak simultan karena kerangka utama selulosa berinteraksi terlebih dahulu dengan inisiator APS. Selanjutnya, selulosa yang telah teraktivasi akan bereaksi dengan campuran monomer AAm dan penaut silang MBAAm. Metode tidak simultan ini digunakan untuk meminimalkan reaksi antarmonomer AAm membentuk homopolimernya.

Tahap awal reaksi kopolimerisasi cangkok dan taut silang melibatkan pembentukan radikal inisiator APS, yaitu $\mathrm{NH}_{4} \mathrm{SO}_{4} \bullet$ (1). Menurut Li et al. (2007) dan Liang et al. (2009), radikal APS akan terbentuk dalam media larutan pada suhu $60-65{ }^{\circ} \mathrm{C}$. Radikal APS akan menyerang gugus hidroksil yang terikat di atom C6 pada struktur selulosa dan mengambil atom hidrogennya sehingga terbentuk radikal makroselulosa (2). Pembentukan radikal makroselulosa ini menjadi tahap inisiasi reaksi kopolimerisasi cangkok dan taut silang karena radikal makroselulosa akan bereaksi dengan monomer AAm membentuk radikal makromolekul lainnya (3). Tahap propagasi dimulai saat radikal (3) bereaksi dengan molekul monomer AAm lainnya membentuk radikal makromolekul (4). Pada tahap terminasi, radikal (4) akan bereaksi dengan radikal makromolekul lainnya dan penaut silang MBAAm membentuk kopolimer cangkok dan taut silang (5). Mekanisme reaksi kopolimerisasi cangkok AAm dan taut silang MBAAm disajikan pada Gambar 1.<smiles>[NH3+]O[15NH2]</smiles><smiles>C[14CH2][14CH2]OS(=O)(=O)[O-]</smiles><smiles></smiles>

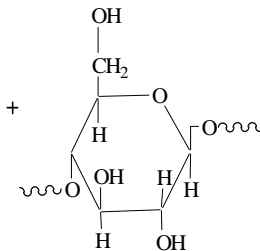

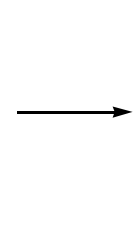

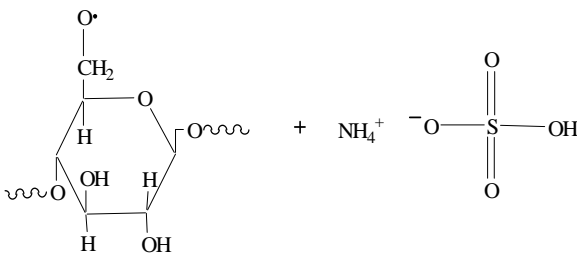

Selulosa

Tahap inisiasi

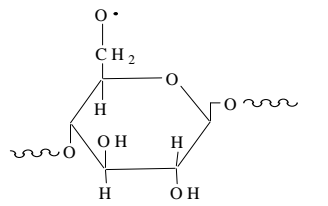<smiles>C=CC(N)=O</smiles>

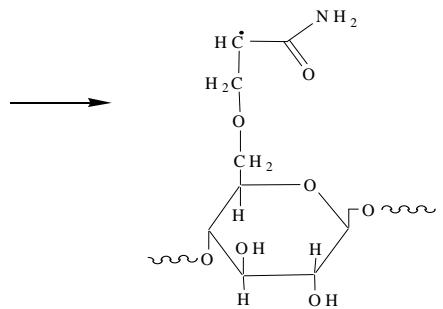

(3) 
Tahap propagasi

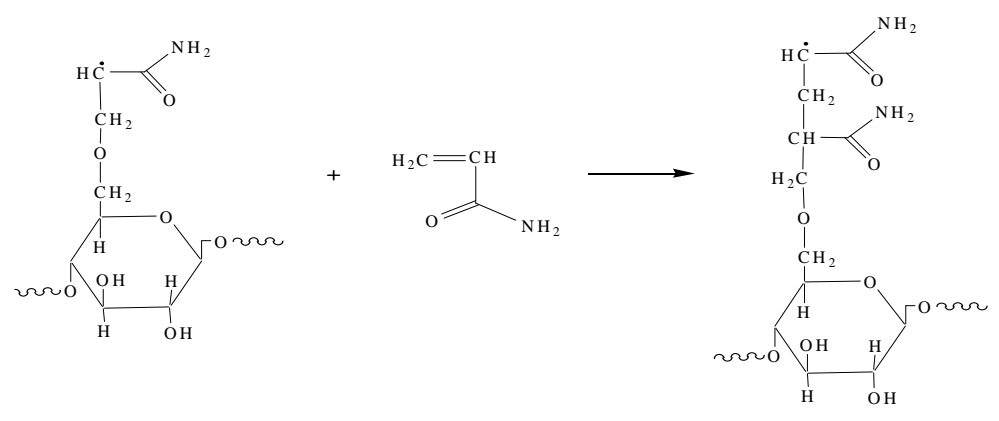

(4)
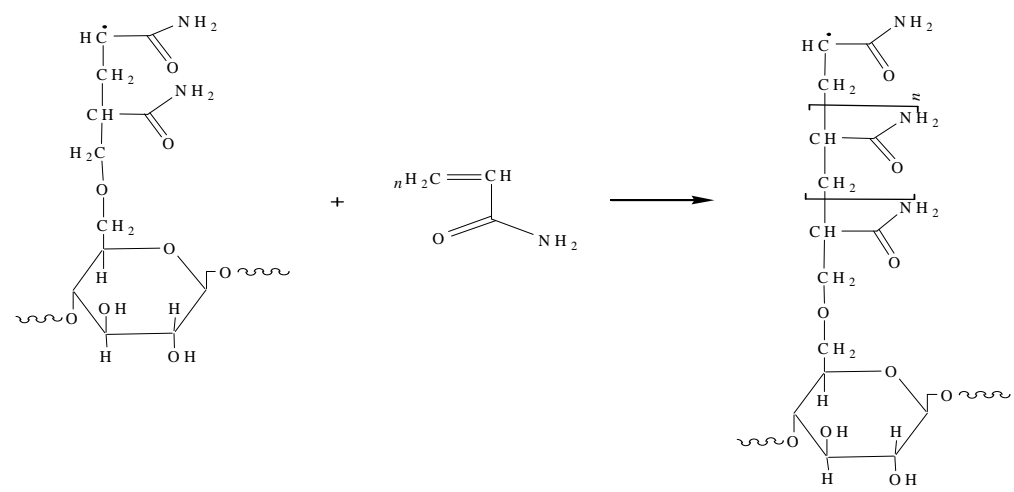

Tahap Terminasi
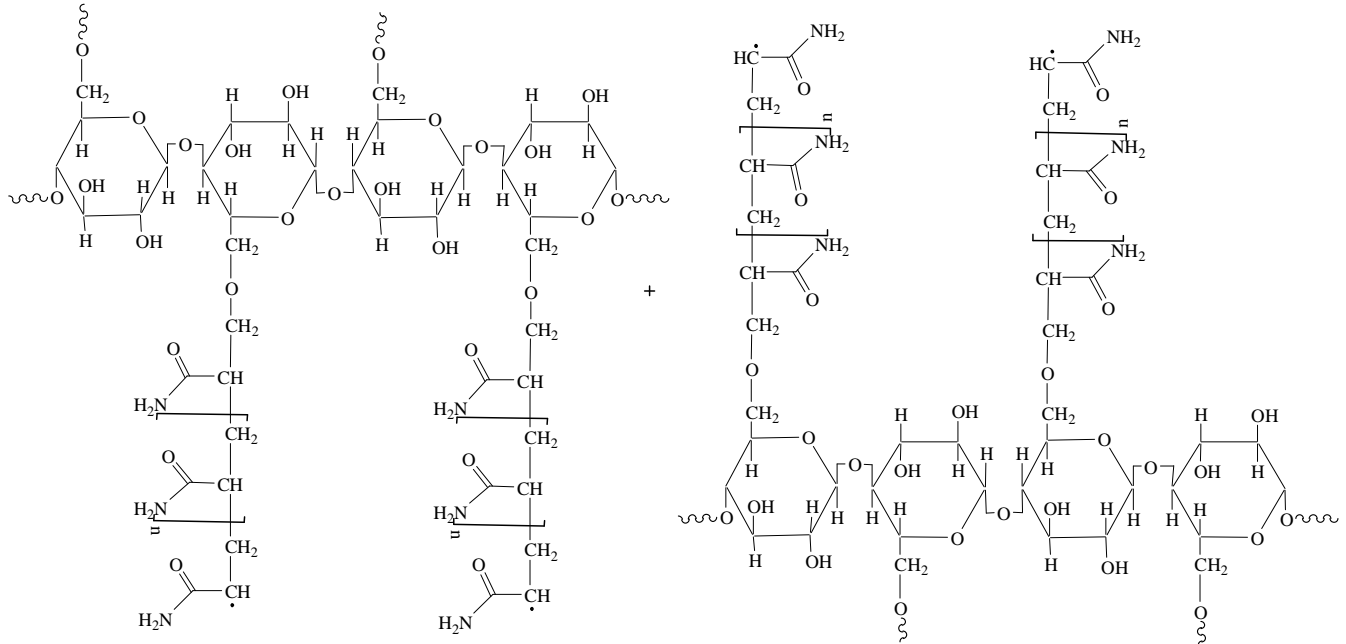

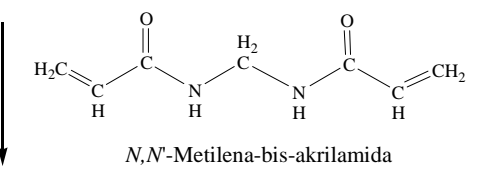




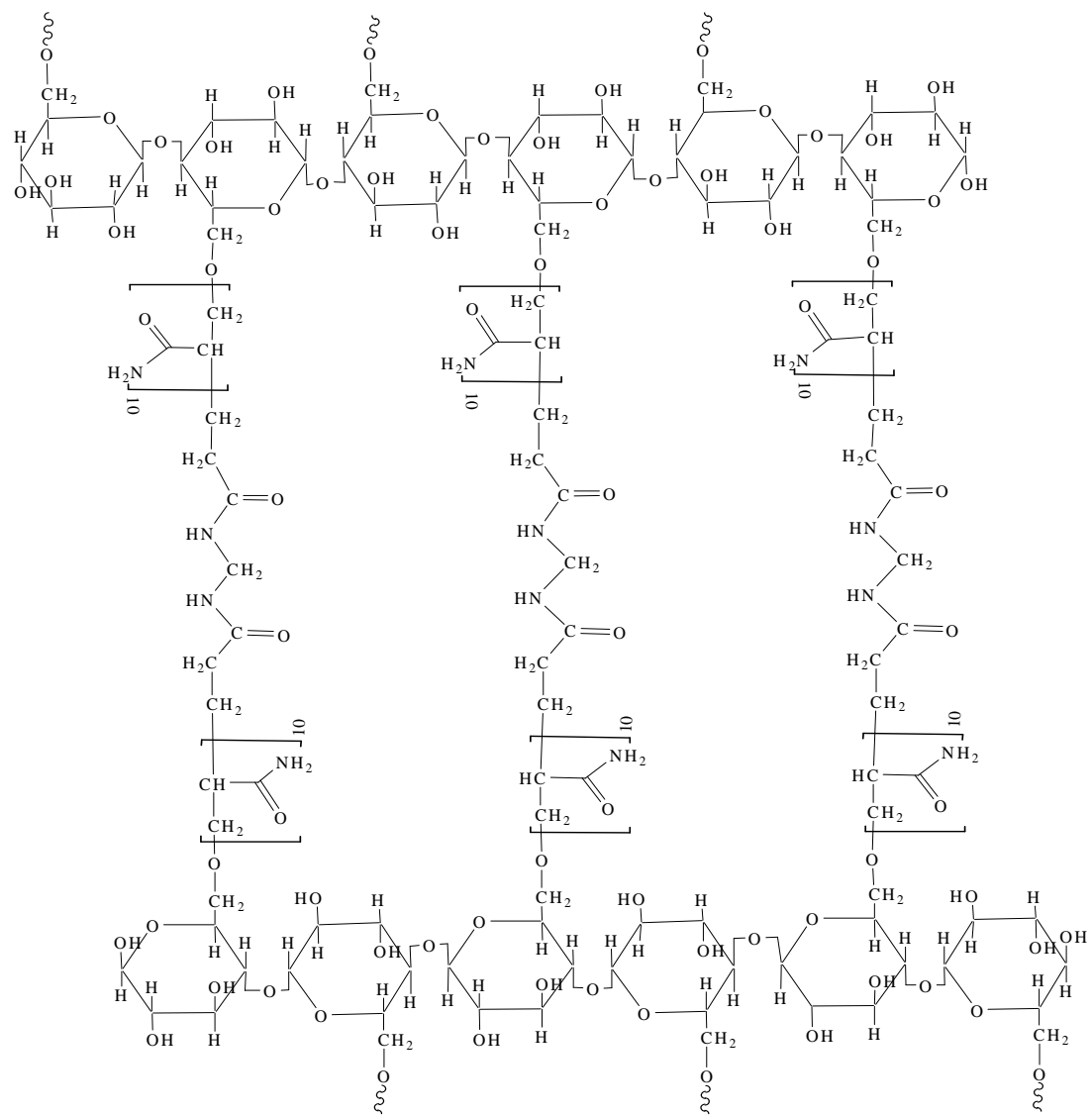

Selulosa tercangkok poliakrilamida

Gambar 1. Mekanisme kopolimerisasi cangkok akrilamida dan taut silang MBA.

Selain reaksi kopolimerisasi cangkok AAm dan taut silang MBAAm pada selulosa, dimungkinkan juga terjadi reaksi pembentukan homopolimer dari monomer AAm. Reaksi pembentukan homopolimer disajikan pada Gambar 2.
Radikal APS yang tidak bereaksi dengan selulosa dapat menginisiasi reaksi homopolimerisasi antarmonomer AAm (6). Selain reaksi ini, tahap propagasi juga mungkin terjadi pada pembentukan homopolimer dari AAm (7). Tahap terminasi juga terjadi pada pembentukan poliakrilamida (8).

Tahap inisiasi<smiles>C=CC(N)=O</smiles>

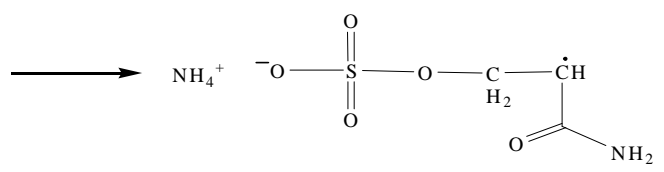

Tahap Propagasi

$$
\text { (n) }
$$


Tahap Terminasi

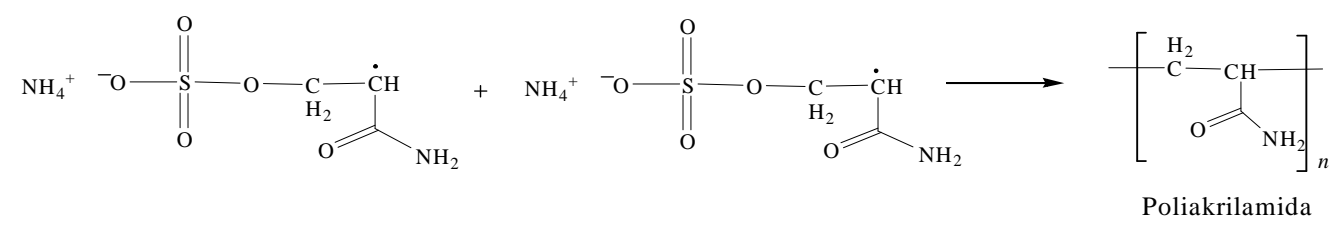

(8)

Gambar 2. Mekanisme pembentukan homopolimer akrilamida.

Banyaknya radikal yang terbentuk pada saat reaksi kopolimerisasi cangkok dan taut silang ini dipengaruhi oleh berbagai variabel, di antaranya konsentrasi monomer, konsentrasi inisiator, konsentrasi penaut silang, waktu reaksi, dan suhu reaksi (Khan et al. 2009). Pengaruh terhadap jumlah penaut silang dipelajari pada penelitian ini. Evaluasi terhadap keberhasilan rekayasa biopolimer salah satunya dilihat melalui nilai kadar nitrogen dari produk hasil rekayasa. Nilai kadar nitrogen ini setara dengan banyaknya AAm yang tercangkok pada selulosa.

Nilai kadar nitrogen, nisbah pencangkokan, dan efisiensi pencangkokan disajikan pada Gambar 3. Nilai kadar nitrogen bervariasi antara 7,85-8,65. Hasil yang diperoleh

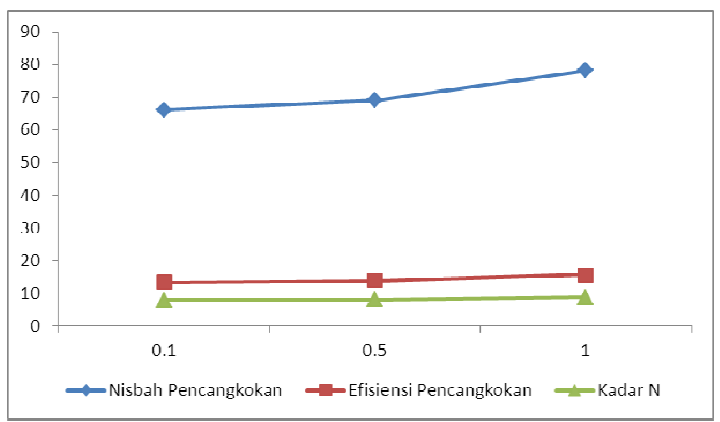

Gambar 3. Pengaruh jumlah penaut silang terhadap kadar nitrogen, nisbah pencangkokan, dan efisiensi pencangkokan.

sejalan dengan yang dilaporkan oleh Huang et al. (2009. Semakin tinggi jumlah penaut silang yang ditambahkan selama reaksi berlangsung, maka kadar nitrogen pada produk pencangkokan dan taut silang juga semakin tinggi. Pola yang sama juga ditunjukkan oleh nisbah pencangkokan dan efisiensi pencangkokan. Nisbah pencangkokan berkisar antara 66,14$78,15 \%$, sedangkan efisiensi pencangkokan berkisar antara 13,23-16,63\%.

\section{Pencirian Produk Hasil Kopolimerisasi Cangkok dan Taut Silang dengan Spektroskopi FTIR}

Spektrum FTIR dari produk hasil rekayasa menunjukkan adanya serapan baru pada bilangan gelombang sekitar $1660 \mathrm{~cm}^{-1}$ karena adanya vibrasi $-\mathrm{C}=\mathrm{O}$ regangan. Hal ini menunjukkan bahwa AAm telah tercangkok pada rantai selulosa. Pada homopolimer poliakrilamida, serapan ini akan muncul pada $1670 \mathrm{~cm}^{-1}$ (Yazdani-Pedram et al. 2002).

Serapan karakteristik -NH pada sekitar $1542 \mathrm{~cm}^{-1}$, $-\mathrm{CN}$ ulur pada $1384 \mathrm{~cm}^{-1}$, dan $-\mathrm{C}-\mathrm{C}-\mathrm{N}$ asimetrik pada $1245 \mathrm{~cm}^{-1}$. Selain itu ada, serapan pada $1566 \mathrm{~cm}^{-1}$ untuk gugus COOasimetrik dan $1416 \mathrm{~cm}^{-1}$ untuk gugus COOsimetrik. Serapan yang lebar sekitar 3100-3500 $\mathrm{cm}^{-1}$ adalah serapan untuk $-\mathrm{OH}$ dan $-\mathrm{NH}_{2}$. Kedua serapan ini menunjukkan serapan yang lebih kuat dibandingkan dengan serapan -OH pada isolat selulosa awal. Puncak yang melebar dan sedikit bergeser ke bilangan gelombang yang lebih kecil disebabkan adanya tumpang tindih serapan $-\mathrm{OH}$ dan $-\mathrm{NH}$ amida dan meningkatnya ikatan hidrogen karena adanya gugus $-\mathrm{COONH}_{2}$. Spektrum produk hasil rekayasa cangkok dan taut silang menunjukkan adanya pergeseran puncak setelah $3000 \mathrm{~cm}^{-1} \mathrm{ke}$ arah bilangan gelombang yang lebih tinggi. Gambar spektra FTIR dari selulosa jerami padi serta produk hasil rekayasa disajikan pada Gambar 4. 


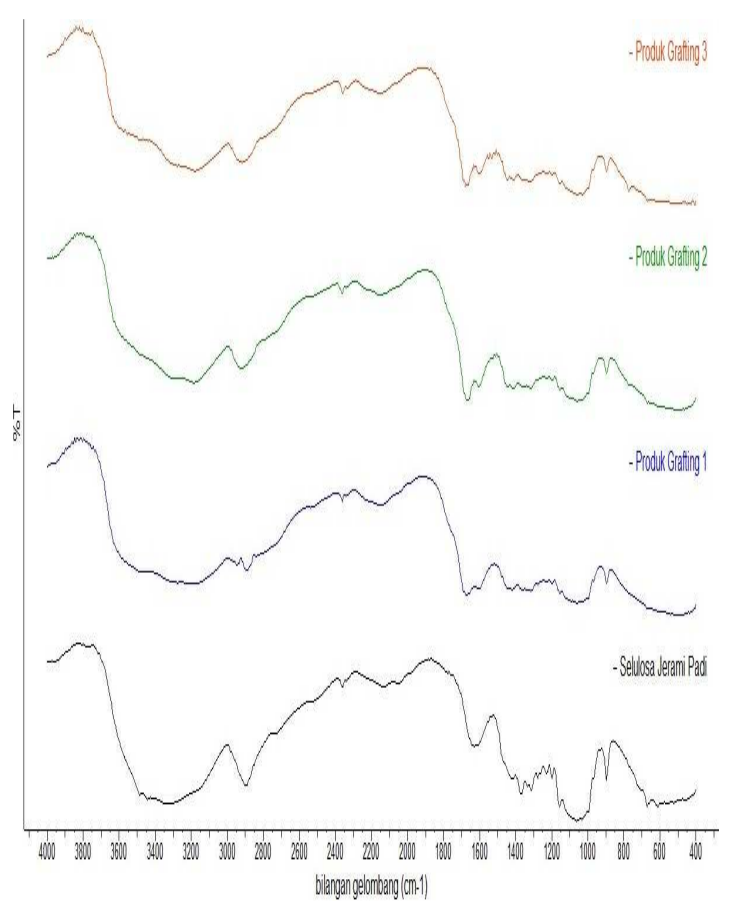

Gambar 4. Spektra FTIR selulosa jerami padi dan produk hasil rekayasa

Evaluasi keberhasilan rekayasa kopolimerisasi cangkok dan taut silang dengan teknik spektroskopi dipantau melalui absorbansi relatif vibrasi selulosa dan produk hasil rekayasa (Tabel 1). Absorbansi relatif adalah nisbah intesitas serapan puncak suatu gugus fungsi pada bilangan gelombang tertentu terhadap intensitas pada bilangan gelombang $\sim 1325 \mathrm{~cm}^{-1}$, yaitu - $\mathrm{CH}$ rocking untuk cincin selulosa (Nada et al. 2007). Rekayasa melalui kopolimerisasi cangkok dan taut silang meningkatkan absorbansi relatif dari vibrasi $\mathrm{C}-\mathrm{H}$ dari $-\mathrm{CH}_{2}$ pada $2924 \mathrm{~cm}^{-1}$. Nisbah intensitas vibrasi $\mathrm{C}-\mathrm{H}$ terhadap intensitas gugus $-\mathrm{OH}$ pada $3576 \mathrm{~cm}^{-1}$ memiliki nilai yang lebih tinggi pada produk hasil rekayasa daripada isolat selulosa awal. Absorbansi relatif pada $1600 \mathrm{~cm}^{-1}$ (serapan karakteristik $\mathrm{C}=\mathrm{O}$ pada gugus amida) akan meningkat dengan meningkatnya jumlah penaut silang. Nisbah intensitas pada bilangan gelombang $1600 \mathrm{~cm}^{-1}$ terhadap intensitas pada $1041 \mathrm{~cm}^{-1}$, yaitu serapan dari ikatan eter (C-O-C) antara unit glukosa pada rantai selulosa, akan meningkat dengan adanya rekayasa karena masuknya gugus $-\mathrm{CONH}_{2}$ pada selulosa. Di samping itu, absorbansi relatif dari
C-O-C pada $1041 \mathrm{~cm}^{-1}$ akan menurun dengan adanya rekayasa jika dibandingkan dengan absorbansi relatif pada selulosa. Hal ini menunjukkan terputusnya ikatan eter pada selulosa selama rekayasa berlangsung. Hasil yang sama juga dilaporkan oleh Nada et al. (2007).

Indeks kristalinitas juga dapat dikaji melalui teknik spektroskopi dengan melihat nisbah intensitas pada $1427 \mathrm{~cm}^{-1}$ terhadap nisbah pada $898 \mathrm{~cm}^{-1}$. Indeks kristalinitas produk rekayasa lebih kecil dibandingkan indeks kristalinitas isolat selulosa awal. Hal ini membuktikan adanya modifikasi melalui kopolimerisasi cangkok dan taut silang karena masuknya gugus amida pada rantai selulosa. Semakin banyak jumlah penaut silang maka indeks kristalinitas akan meningkat.

\section{Mikroskopi Pemayaran Elektron}

Teknik SEM merupakan salah satu teknik yang dapat digunakan untuk melihat morfologi permukaan pada berbagai jenis polimer. Sebagai bukti bahwa rekayasa melalui cangkok dan taut silang telah berhasil dilakukan adalah dengan cara membandingkan mikrograf dari isolat selulosa dengan produk hasil rekayasa. Morfologi permukaan dari ketiga isolat selulosa sangat berbeda jika dibandingkan dengan mikrograf produk hasil rekayasa. Pada mikrograf isolat selulosa tampak bentuk fibril dari selulosa, sedangkan pada mikrograf produk hasil rekayasa tidak ditemukan bentuk fibril. Gambar 5 adalah mikrograf dari selulosa jerami padi serta produk hasil rekayasa.

\section{Analisis Termal}

Dekomposisi bahan selulosa terjadi melalui kombinasi proses dehidrasi, dekarboksilasi, dan dekarburasi/dekarbonisasi. Untuk melihat perubahan sifat fisikokimia setelah kopolimerisasi cangkok dan taut silang, maka analisis termal berupa DTA diamati. Kehilangan massa (11-15\% untuk sampel selulosa) mulai terjadi pada $96{ }^{\circ} \mathrm{C}$, yaitu kehilangan air yang terikat secara fisik dan umum terjadi pada bahan-bahan yang mengandung selulosa (Zhang et al. 2010). Pirolisis selulosa mulai terjadi pada suhu $\mathrm{T}=197$ ${ }^{\circ} \mathrm{C}$. Kurva DTA menunjukkan ada 2 puncak (270 
${ }^{\circ} \mathrm{C}$ dan $349{ }^{\circ} \mathrm{C}$ ) yang merupakan dekomposisi termal dari selulosa yang berupa dekarboksilasi dan dekarburasi/dekarbonisasi. Selain itu, kurva DTA juga membuktikan bahwa modifikasi kimia telah terjadi pada isolat selulosa karena adanya pergeseran suhu dekomposisi selulosa awal dan homopolimer poliakrilamida.

Tabel 1. Absorbansi relatif isolat selulosa dan produk hasil rekayasa jerami padi

\begin{tabular}{|c|c|c|c|c|c|}
\hline \multirow{2}{*}{$\begin{array}{c}\text { Bilangan } \\
\text { Gelombang }\left(\mathrm{cm}^{-1}\right)\end{array}$} & \multirow[t]{2}{*}{ Gugus Fungsi } & \multicolumn{4}{|c|}{ Absorbansi relatif } \\
\hline & & Selulosa & Produk 1 & Produk 2 & Produk 3 \\
\hline 3576 & $\mathrm{OH}$ & 1,20 & 0,93 & 0,89 & 1,15 \\
\hline 2924 & $\mathrm{CH}_{2}$ & 0,98 & 0,95 & 0,86 & 1,18 \\
\hline 2850 & $\mathrm{CH}_{2}$ & 1,00 & 0,91 & 0,88 & 1,03 \\
\hline 1600 & $\mathrm{CONH}_{2}$ & & 0.97 & 0.99 & 1,20 \\
\hline 1427 & $\begin{array}{l}\text { Selulosa } \\
\text { kristalin I }\end{array}$ & 1,25 & 1,00 & 1,00 & 1,22 \\
\hline 1041 & $\mathrm{C}-\mathrm{O}-\mathrm{C}$ & 1,44 & 1,31 & 1,08 & 1,07 \\
\hline 898 & $\beta$-glikosida & 0,95 & 0,95 & 0,96 & 1,12 \\
\hline Nisbah 1600/1041 & $\mathrm{CONH}_{2} / \mathrm{C}-\mathrm{O}-\mathrm{C}$ & - & 0,74 & 0,95 & 1,12 \\
\hline Nisbah 2924/3576 & $\mathrm{CH}_{2} / \mathrm{OH}$ & 0,83 & 0,98 & 0.96 & 0,89 \\
\hline Nisbah 1427/898 & $\mathrm{CrI}$ & 1,32 & 1,05 & 1,04 & 1,09 \\
\hline
\end{tabular}

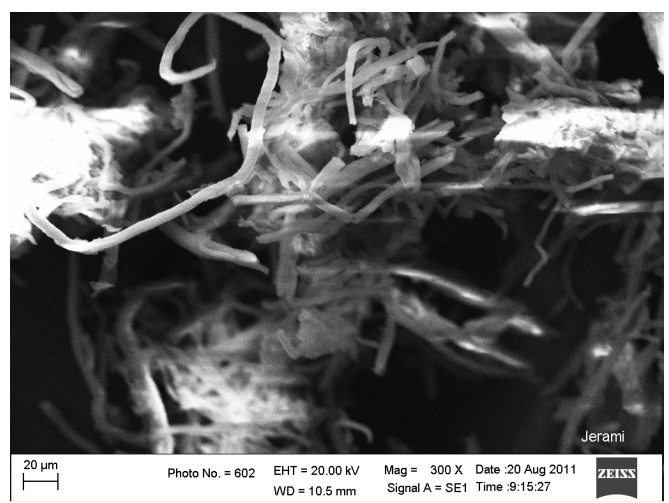

Selulosa jerami padi

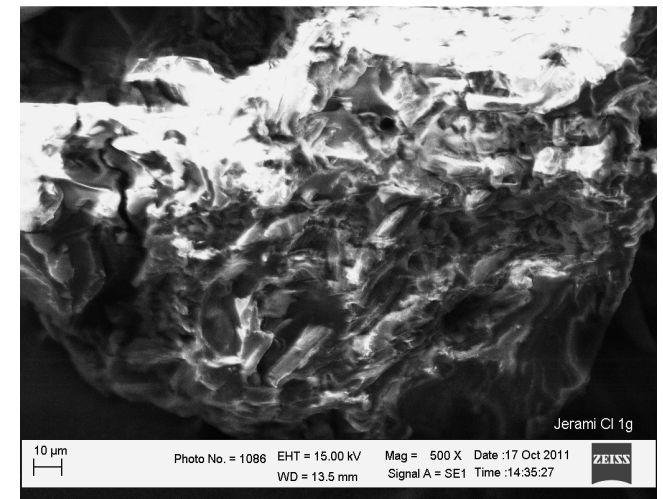

Produk hasil rekayasa

Gambar 5. Mikrograf selulosa jerami padi dan produk hasil rekayasa.

Suhu dekomposisi semakin tinggi dengan semakin banyaknya jumlah penaut silang. Produk hasil kopolimerisasi cangkok dan taut silang memiliki struktur kristalin yang lebih banyak, sehingga membutuhkan suhu yang lebih tinggi untuk terdekomposisi. Produk hasil rekayasa lebih tahan terhadap termal/panas dibandingkan dengan selulosa. Hal ini sejalan dengan indeks kristalinitas dari produk hasil rekayasa yang semakin tinggi dengan bertambahnya jumlah penaut silang. Gambar 6 menunjukkan kurva DTA dari selulosa, homopolimer, dan produk hasil rekayasa.

\section{Swelling Capacity}

Pengaruh penambahan penaut silang terhadap swelling capacity atau daya serap air dikaji dengan meningkatkan jumlah $N, N^{\prime}$ metilena-bis-akrilamida (MBAAm) secara bertahap. Selain itu, pengaruh saponifikasi terhadap daya serap air juga diamati. Hasil uji daya serap produk hasil kopolimerisasi cangkok dan taut silang merupakan informasi awal kemampuannya sebagai material penjerap (Gambar 7). 


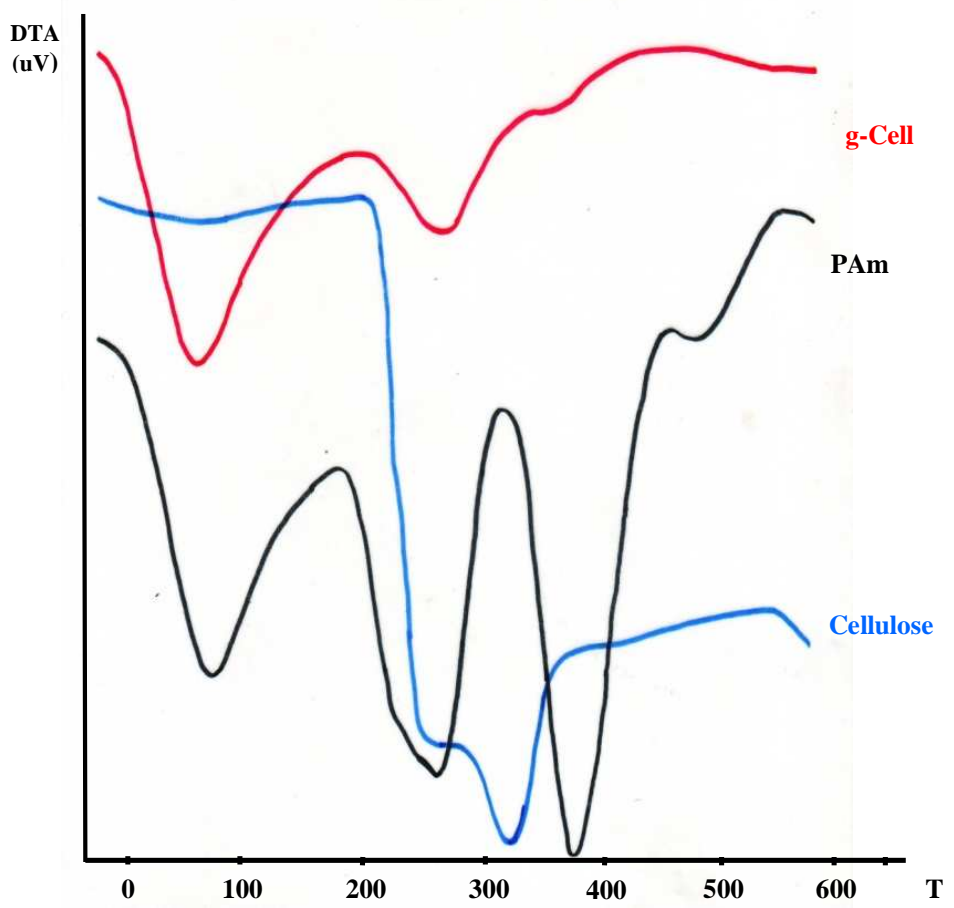

Gambar 6. Kurva DTA selulosa, homopolimer, dan produk rekayasa dari jerami padi.

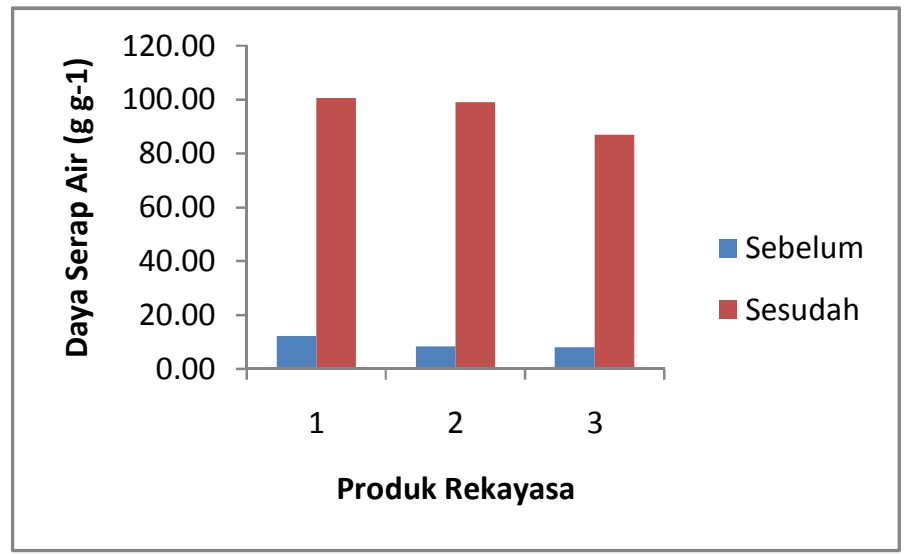

Gambar 7. Kurva daya serap air sebelum dan sesudah hidrolisis

Sebelum saponifikasi, produk hasil rekayasa dari jerami padi dengan jumlah MBAAm sebesar $0,1 \mathrm{~g}$ memiliki swelling capacity yang paling tinggi, yaitu $8,16\left(\mathrm{~g} \mathrm{~g}^{-1}\right)$. Penambahan jumlah penaut silang akan menurunkan daya serap air. Hasil yang sama juga dilaporkan oleh Khan et al. (2009). Peningkatan jumlah penaut silang akan meningkatkan kerapatan dari jaring (network) dan ikatan taut silang dari produk sehingga struktur rangka polimer secara keseluruhan menjadi kaku dan sulit untuk menyerap sejumlah air.

Reaksi saponifikasi dapat meningkatkan daya serap air seluruh produk hasil modifikasi. Hasil yang sama juga dilaporkan oleh Saikia \& Ali (1999). Perlakuan dengan alkali akan mengkonversi $-\mathrm{CONH}_{2}$ menjadi $-\mathrm{COOH}$, dan $\mathrm{COO}^{-}$(Gambar 8). Jumlah dan variasi gugus hidrofilik seperti $-\mathrm{CONH}_{2},-\mathrm{COOH}$, dan $-\mathrm{COO}^{-}$ 
akan mempengaruhi daya serap air dari masingmasing produk. Peningkatan swelling capacity akibat reaksi saponifikasi bervariasi 5-10 kali swelling capacity awalnya. Swelling capacity tertinggi setelah reaksi saponifikasi dicapai oleh produk 1 , yaitu produk hasil rekayasa dengan jumlah penaut silang $0,1 \mathrm{~g}\left(100.64 \mathrm{~g} \mathrm{~g}^{-1}\right)$.

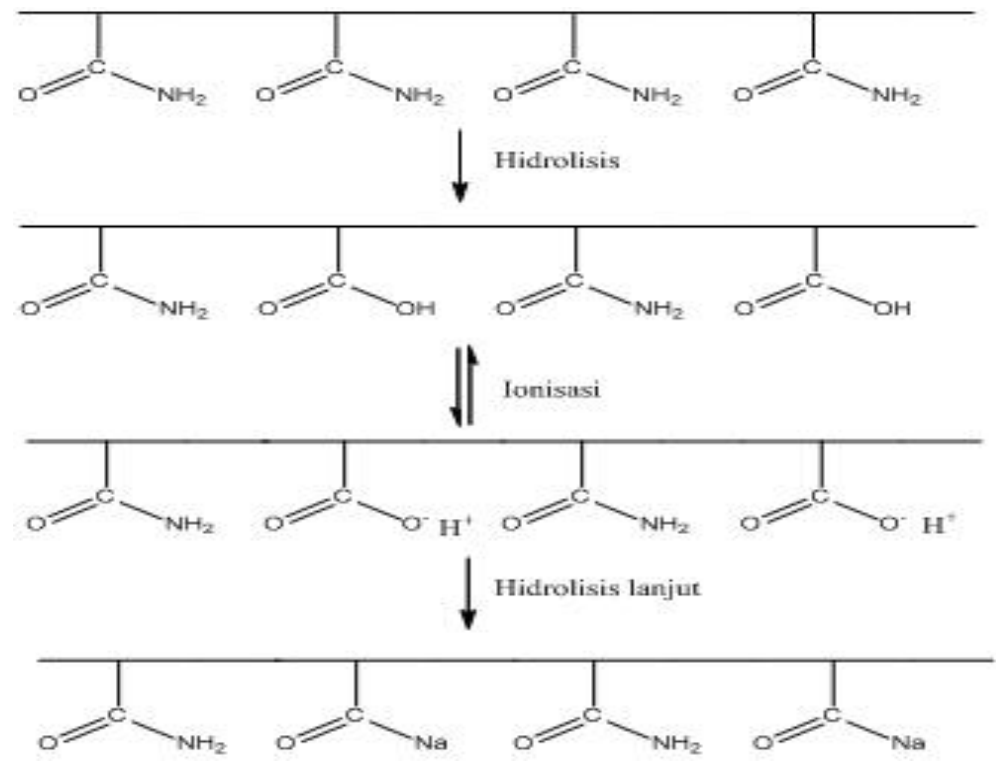

Gambar 8. Hidrolisis parsial gugus amida pada rantai poliakrilamida.

\section{KESIMPULAN DAN SARAN}

\section{Kesimpulan}

Rekayasa biopolimer dari jerami padi melalui kopolimerisasi cangkok dan taut silang telah dilakukan. Nisbah dan efisiensi pencangkokan berturut-turut adalah 66,14$78.15 \%$ dan 13,23-16.63\%. Nilai nisbah dan efisiensi pencangkokan meningkat dengan meningkatnya jumlah penaut silang. Hasil pencirian dengan teknik spektroskopi menunjukkan adanya serapan gugus amida yang membuktikan kopolimerisasi cangkok dan taut silang telah terjadi. Morfologi permukaan produk rekayasa tidak lagi berbentuk fibril, melainkan permukaan yang kasar dan berongga. Semakin meningkat jumlah penaut silang, permukaan semakin kasar dan berongga. Indeks kristalinitas meningkat dengan meningkatnya jumlah penaut silang. Analisis termal menunjukkan bahwa produk hasil rekayasa lebih tahan secara termal karena terdekomposisi pada suhu yang lebih tinggi. Kajian terhadap swelling capacity produk hasil rekayasa ini menunjukkan bahwa dengan meningkatnya jumlah penaut silang maka swelling capacity akan semakin menurun. Hidrolisis produk hasil rekayasa terbukti dapat meningkatkan swelling capacity sampai 12,5 kali.

\section{Saran}

Optimasi proses rekayasa perlu dilakukan dengan memperhatikan variabel proses yang mempengaruhi kinerja produk sebagai material penyerap.

\section{DAFTAR PUSTAKA}

1. Crini G. 2005. Recent development in polysaccharide-based materials used as adsorbents in wastewater treatment. Prog. Polym Sci. 30: 38-70.

2. Doane WM, Doane SW, Savich MH. 2009. Superabsorbent polymers in agricultural applications. US Patent US2009/0069185 A1 
3. El-Mohdy HIA, El-Rehim HAA. 2009. Radiation synthesis of kappa-carragenan/acrylamide graft copolimers as superabsorbents and their possible applications. J Polym Res. 16:63-72.

4. Enomoto-Rogers Y, Kamitakahara H, Nakayama K, Takano T, Nakatsubo F. 2009. Synthesis and thermal properties of poly(methyl methacrylate)graft-(cellobiosylamine-C15). Cellulose. 16:519530.

5. Huang Z, Liang X, Hu H, Gao, L Chen Y, Tong Z. 2009. Influence of mechanical activation on the graft copolymerization of sugarcane bagasse and acrylic acid. Polymer Degradation and Stability. 94:1737:1745.

6. Khan GMA, Shaheruzzaman Md, Rahman MH, Razzaque SM. 2009. Surface modification of okra bast fiber and its physico-chemical characteristics. Fiber and Polymers 10:65-70.

7. Kim S, Dale BE. 2004. Global potential bioethanol production from wasted crops and crop residues. Biomass and Bioenergy 26:361375

8. Li A, Zhang J. Wang A. 2007. Utilization of starch and clay for the preparation of superabsorbent composite. Biores Technol 98:327-332.

9. Liang R, Yuan H, Xi G, Zhou Q. 2009. Synthesis of wheat straw-g-poly(acrylic acid) superabsorbent composite and release of urea from it. Carbohydrate Polymers 77:181-187

10. McDowall DJ, Gupta BS, Stannett VT. 1984. Grafting of vinyl monomers to cellulose by ceric ion initiation. Prog. Polym. Sci. 10:1-50.

11. Nada AMA, Alkady M, Fekry HM. 2007. Synthesis and characterization of grafted cellulose for use in water and metal ions sorption. BioResources 3:46-59

12. Princi E, Vicini S, Proietti N, Capitani D. 2005. Grafting polymerization on cellulose based textiles: a ${ }^{13} \mathrm{C}$ solid state NMR characterization. European Polymer Journal. 41:1196-1203.

13. Saikia CN, Ali F. 1999. Graft copolymerization of methylmethacrylate onto high $\alpha$-cellulose pulp extracted from Hibiscus sabdariffa and Gmelina arborea. Bioresource Technology 68:165-171

14. Yazdani-Pedram M, Lagos A, Retuert PJ. 2002. Study of the effect of reaction variables on grafting of polyacrylamide onto chitosan. Polymer Bulletin 48:93-98.
15. Zhang M, Qi W, Liu R, Su R, Wu S, He Z. 2010. Fractionating lignocelloluse by formic acid: Characterization of major components. Biomass and Bioenergy 34:525-532. 